\title{
Does IFRS 9 Consider Financial Statement Users' Preferences with Respect to IFRS 13 Fair Value Hierarchy? A Suggestion to Refine the Definition of OCI
}

\author{
FELIPE M. HERRANZ MARTÍN ${ }^{\text {a }}$, BEATRIZ GARCÍA OSMA \\ a Universidad Autónoma de Madrid, Facultad de CC.EE.y EE., c/ Francisco Tomás y Valiente, 5, \\ 28049 Madrid, España. E-mail: felipe.herranz@uam.es \\ b Universidad Carlos III de Madrid, Facultad de Ciencias Sociales y Jurídicas, c/Madrid, 126, 28903 \\ Getafe (Madrid), España. E-mail: bgosma@emp.uc3m.es
}

\begin{abstract}
The use of fair value in firms' financial statements has created a lively debate both among academics and professionals. In this paper, we: (i) analyse the evolution of the objectives, priorities and direction of accounting; (ii) identify the antecedents to fair value and the current mixed model; (iii) briefly review the techniques in IFRS 13 to calculate fair value, and their hierarchical levels; (iv) analyse the use (or lack of use) of these fair value hierarchies under IFRS (and particularly, the IFRS 9 case); (v) compare IFRS 9 focus with the preferences of financial statements' users with respect to fair value levels; and (vi) suggest a plausible long-term solution that reconciles the preferences of financial statement users with the techniques contained in existing regulation by suggesting a plausible refinement to the definition of OCI.
\end{abstract}

Keywords: Fair Value, Fair Value Hierarchy, IFRS 9, Financial Statement Users' Preferences, Other Comprehensive Income Definition, Accounting Conceptual Framework, OCI.

\section{¿Considera la NIIF 9 las preferencias de los usuarios en relación con la jerarquía de cálculo del valor razonable establecida en la NIIF 13? Una propuesta de mejora de la definición de OCI}

\section{RESUMEN}

El uso del valor razonable en los estados financieros de las empresas es un tema de continuo debate tanto en el mundo académico como en el profesional. En este trabajo nos planteamos los siguientes objetivos: (i) analizar la evolución de los objetivos, las prioridades y los enfoques de las normas contables; (ii) identificar los antecedentes más próximos del valor razonable y del modelo mixto actual; (iii) señalar brevemente las técnicas de cálculo del valor razonable ofrecidas por el IFRS 13 con sus niveles jerarquizados; (iv) analizar el uso (o la falta de uso) de las jerarquías de valor razonable en las normas IFRS (particularmente en el IFRS 9); (v) comparar el enfoque del IFRS 9 con las preferencias de los usuarios de los estados financieros respecto a los distintos niveles de cálculo del valor razonable; y (vi) ofrecer una posible solución a largo plazo para conciliar las preferencias de los usuarios con las técnicas ofrecidas por las normas, sugiriendo una posible mejor a la definición de OCI.

Palabras clave: Valor razonable, jerarquías valor razonable, IFRS 9, preferencias usuarios información financiera, definición de OCI, marco conceptual, OCI.

JEL Classification: G38, K22, M41

Artículo recibido en marzo de 2018 y aceptado en abril de 2018

Artículo disponible en versión electrónica en la página www.revista-eea.net, ref. ə-36210

ISSN 1697-5731 (online) - ISSN 1133-3197 (print) 


\section{ACCOUNTING OBJECTIVES IN CONFLICT}

A number of objectives have been incorporated to accounting through time. Oftentimes, the newly created objectives were prioritized, but that did not mean that existing objectives disappeared from business. Without meaning to be exhaustive, but in chronological order, we could summarize these fundamental objectives as follows. First of all, we can mention 'registry' or accountability as a primordial objective, at the very origins of accounting. Data on the accumulation and changes in wealth was necessary to control, safeguard and manage it, and "it is easier to orally record and transmit stories, ideas, thoughts, etc., than numerical and economic data" (Muñoz and Hernanz, 2010). This registry objective, that predates modern commercial relations and the use of money, was essential at the time that double-entry bookkeeping become known in the late XV Century, constituting the earliest antecedent of what is nowadays understood as accounting.

This initial objective was eventually displaced by other objectives, which gained prominence subsequently. The legal objective was soon incorporated. It naturally emerged linked to the monitoring provided by the verifiable, hard-tomanipulate, methods used in bookkeeping, which permitted the use of accounting as evidence in litigious contexts. Closely aligned to this objective, the use of accounting to calculate taxable income and to calculate the basis of a number of other taxes became also a fundamental objective. The aforementioned characteristics of accounting turned it into a perfect vehicle to facilitate tax collection. The protection of creditors and more generally, of stakeholders, from managerial expropriation has also featured as a basic objective of accounting, as a highly useful instrument to aid in the control of businesses by public entities. Indeed, the prudence necessary to avoid firm equity depletion, the creation and enforcement of specific criteria to calculate distributable profit and other similar elements represent a substantive contribution of accounting to this objective.

The final objective added to accounting, which currently stands as the most relevant one, is that of providing useful (relevant and faithfully represented) information to the users of financial statements, which are mainly considered to be current and future investors and debt-holders. This is the "decision usefulness paradigm" (see, e.g., Cañibano et al., 1999).

As noted, new objectives are usually prioritized, and therefore, they are given pre-eminence over existing objectives. However, the incorporation of novel objectives does not usually result in the overriding of prior objectives, which are maintained, but given a lower rank relative to the newly added ones. Necessarily, this means that when new objectives are incorporated, conflicts are likely to appear -at least temporarily, until clarity emerges on how precisely to maintain the prior objectives, if they are still considered necessary. This process 
may also require that other legal systems are altered or developed to contribute to supply what accounting abandons, at least as a main objective.

Some of these conflicts have found adequate resolutions. For example, the registry and legal objectives still apply. Legislations across countries have adapted to the emergence of modern information systems. Increasingly technologically advanced bookkeeping and accounting have been legalized to provide an answer to these objectives. In spite of this, it is also noteworthy that accounting, in fitting with the current regulatory view of providing information useful to financial statement users, has become increasingly independent and separate from pure bookkeeping.

A different solution applies to the role of accounting in fiscal calculations, as this objective is no longer considered a priority. However, in a number of countries, while fiscal regulations are separate from accounting ones, book-tax conformity remains high, and information from the financial statements is still used to, after adjustments to reconcile tax and accounting differences, calculate the magnitudes that serve as the basis to determine and pay taxes. These tax expenses and payments are then, in turn, measured and included into the firm financial statements, using accounting principles. Thus, we can conclude that this conflict has also been resolved to the satisfaction of the different parties.

Importantly, the conflict between the protection of stakeholders' interests to avoid managerial expropriation and the decision usefulness objectives has not been yet resolved; given that, at present, the link between accounting profit and distributable profit still has a significant weight in practice. Indeed, the 'marriage' between corporate law and accounting regulation is possibly the hardest one to dissolve, and certainly harder to separate than the one between tax and accounting rules.

This influence of stakeholders' protection over accounting rules, whether direct or indirect, often introduces complexity in the process necessary to separate realized from unrealized profits, or to maintain prudence as a desirable qualitative characteristic of accounting when it is in conflict with information relevance, among other issues.

Concerns surrounding this conflict would be attenuated if corporate regulations worldwide were more precise in determining patrimonial protection cases and assumptions, which would then not need to coincide with accounting criteria under the decision usefulness paradigm. For example, corporate regulation can use (and it sometimes does) particularly prudent criteria for the calculation of distributable profit, or to establish the methods to calculate minimum capital requirements, or to determine bankruptcy or the dissolution of firms when those minimum requirements are not met. Other examples of owners' equity protection that do not coincide with accounting regulations can be found in 
the Basilea parameters, compulsory for financial firms, and that contain recommendations that are followed by most developed economies worldwide. ${ }^{1}$

However, a number of events surrounding the recent financial crisis provide evidence of a questionable use of accounting profit, not only to distribute dividends, but also, to enable the payment of bonuses to top managers in large companies. This has also spurned undesired practices leading to paradoxical cases, where firms that had reported large profits, and thus, paid similarly large dividends and bonuses, have subsequently run into serious financial health problems leading to immediate bankruptcy or governmental bail outs by means of large government financial aids. These cases have appeared in many different countries, and led, for example, to US president Obama publicly declaring his disagreement with the payment of large bonuses to top managers in firms that were experiencing financial difficulties and required governmental bail outs. ${ }^{2}$

These complex interrelations of accounting regulation with other regulations likely affect the timing and plausibility of a complete separation of accounting from the principles associated with the protection of firm owners' equity and patrimonial protection, limiting the extent to which accounting can evolve with the exclusive objective of providing public financial statements that contain information that is relevant and faithfully represented. In any case, the persistence of this relation, linked to patrimonial protection and distribution of dividends and bonuses, is an important feature of accounting that we would like to highlight in the context of our study of the use of fair value accounting.

The remainder of the paper is structured as follows. Sections 2 and 3 discuss the existing international accounting regulation and the antecedents of the fair value concept. Evidence on the preferences of financial statements users are discussed in section 4, while section 5 presents the fair value measurement and hierarchy under IFRS 13 "Fair Value Measurement" (IASB 2011). This definition is contrasted with IFRS 9 "Financial Instruments" (IASB 2014) use of the fair value concept in section 6 . Finally, section 7 presents a long term proposal to reconcile existing regulation with the preferences of users, through a refinement in the definition of OCI and section 8 concludes.

\section{ACCOUNTING REGULATION APPROACHES AND INTERNATIONAL CONVERGENCE}

Accounting regulation in the last century has evolved differently in different countries and geographical areas. A number of accounting classifications are possible (see, e.g., Nobes 1983, 2014), but we could note the existence of a

\footnotetext{
${ }^{1}$ See, e.g., the Basel Committee Membership at http://www.bis.org/bcbs/membership.htm

2 “Obama Calls Wall Street Bonuses 'Shameful' http://www.nytimes.com/2009/01/30/business/ 30obama.html”.
} 
'professional' approach to the preparation of accounting rules, which is common in Anglo-Saxon countries, and a more 'legally' grounded approach, which is common in continental European countries. In the professional model, accounting standards are prepared by independent professional bodies, while in the legal approach it is the country's general legal regime and bodies which are also in charge of preparing national accounting standards. In the professional model, the information objective has achieved greater weight, whilst in the legal approach the objectives associated with firm control, tax calculation and the protection of stakeholders' interests have been essential.

This duality manifested itself for many years, leading to large differences in accounting regulations worldwide. Even nowadays it has not entirely disappeared, despite the many advances made towards the international converge of accounting standards. For example, all publicly quoted consolidated firms in the European Union (EU) must use IASB prepared standards (International Financial Reporting Standards, IFRS) to present their consolidated financial statements, however, all other financial statements (from private firms, and individual financial statements) can be prepared using either IFRS or national accounting standards as decided by each Member State of the EU.

Within each of these two models, differences also exist. The professional model has given rise to different approaches in the development of accounting regulation. If we compare the approaches at the root of the two bodies that currently are the major issuers of accounting standards worldwide, the FASB and the IASB, we can observe that, while the former one (the FASB) has favoured the issuance of detailed rules to achieve a great degree of accounting quality, the latter body (the IASB) has favoured the preparation of principles.

For many years, the principles-based model was considered of lower quality, as it was accused of lacking precision. This lack of precision was likely a consequence of the difficulties in reaching international consensuses between the many countries that use international regulations and participate in and influence their preparation. However, recent events, such as the Enron accounting scandal, demonstrated the weaknesses inherent to an exaggeratedly detailed regulation, which could facilitate the 'design' of transactions exclusively aimed at lowering transparency or at manipulating the information that firms provide. This led academics and professionals to questioning whether principles-based accounting regulation could have been more efficient in preventing such accounting scandals.

A principles-based approach could be seen as a better fit for the 'true and fair view' that has been introduced in many jurisdictions, including recently issued EU Directives. While it is true that IASB-prepared standards do not mention this important accounting view as explicitly as it is mentioned by EU accounting Directives, it is widely accepted that this view is embedded into the international standards prepared by the IASB, even though it is often subsumed 
into requirements that have different denominations. Specifically, it can be considered that the expression 'fair presentation' that is found in standards prepared by the IASB is equivalent to the 'true and fair view.'3

True and fair view is a key concept that gives preference to the true and faithful representation of the underlying transactions and information, over any other considerations. The true and fair view is often achieved by precisely applying accounting standards; however, exceptional cases may exist where the application of specific accounting standards does not lead to the attainment of this non-renounceable objective. In those cases, true and fair view may mean the use of those measurement and valuation principles that best guarantee the decision usefulness of information, in place of any explicit and detailed existing accounting regulation. This aims to avoid situations where financial statement users' could not 'see the forest for the trees.' In addition, this preference for principles-based standards became particularly prominent during the FASB and IASB convergence project, ${ }^{4}$ where a certain agreement existed that the resulting common standards would be principles-based.

A clear example, in our view, of the weaknesses associated with the application of rules-based standards can be found in the recent financial crisis in Spain, where a careful application of the rules impeded the true and fair recognition of the underlying economic substance of the operations. Indeed, from the pure application of the rules perspective, the re-financing that many banks granted to financially unhealthy firms eliminated concerns, and thus, meant there was no need to recognize impairments to financial assets because of delays in payments. However, from a principles-based view, the re-financing itself was a relevant event that signalled the insolvency of the debtors, requiring the recognition of impairments (see, for details, Cañibano and Herranz 2013). ${ }^{5}$

This insufficient global convergence of accounting standards and of their associated models (professional and legal), as well as the persistence of both rules- and principles-based standards within the international sphere provides a

\footnotetext{
${ }^{3}$ See Financial Reporting Council, July of 2011. https://www.frc.org.uk/getattachment/55214e7d6e34-4c11-af51-1b0533ec0c95/Paper-True-and-Fair1.pdf

${ }^{4}$ The 2002 Norwalk agreement, between the FASB and the IASB, has given rise to many joint documents and initiatives, but has not translated into any common standards. At the time of writing this article, it seems that this initiative has lost some of its initial impulse, as the convergence process is not going through its better times, and some may consider it as effectively cancelled (http://ww2.cfo.com/gaap-ifrs/2014/10/split-convergence/).

${ }^{5}$ Spanish banks agreed to re-finance loans to firms going through financial distress, to avoid recognizing impairments. The rule set by the Bank of Spain at the time, if mechanistically applied, considered that impairments should be recognized on the basis of number of days since the repayment default. By refinancing the loans, this date could be pushed forward and avoid recognizing the impairment (see, e.g., Delgado 2012; Barrón 2013).
} 
context to understand a number of the issues in the application of the fair value accounting concept and hierarchy that we detail in the following sections.

\section{FAIR VALUE ANTECEDENTS AND THE MIXED MODEL}

Under different denominations, fair value has been used in firms' financial statements for decades, particularly before the Great Depression that started with the 1929 crisis, a time when accounting practice was far from homogenous. In the following decades, concerns over improving the objectivity and verifiability of financial statements prepared by companies gave rise to the use of historical cost as the core measurement basis (Morales, 2017, p. 100). This tendency was sustained for many years, and indeed, in some jurisdictions, the historical cost or acquisition price criteria was not only a measurement basis but an accounting principle in itself.

Measurement criteria similar to fair value were slowly introduced into accounting, but always as auxiliary to the dominant historical cost basis. For example, certain asset revaluations related with the application of inflation indexes commonly followed the lower of cost or market value principle, setting the fair value as the maximum value of the assets. Similarly, the recoverable amount of assets, needed when trying to ascertain the existence of impairments, has used criteria akin to fair value, as the value in use is measured using market prices or discounted future cash flows.

However, during the 1980s and 1990s, and particularly in the wake of scandals associated with the use of derivatives and hedging, where latent, unrealized, losses were not reflected in firm financial statements, the increasing criticism over existing accounting practices put pressure on accounting standard setters to revise accounting measurement criteria. While the causes underpinning the large losses associated with the use of derivatives could be attributable to inappropriate procedures in the segregation of functions, or to the inadequate knowledge of derivatives (Herranz 2001, p.107), it is also true that the use of the historical cost of derivatives -often zero or insignificant, did not provide true and fair information of the firm financial position.

As a consequence, a process started (still ongoing to a certain extend), where the leading international accounting standard setters tried to define novel general criteria in response to these newly identified information needs. The first response was offered by the FASB in 1996, through four key decisions (see, for details, Herranz Martín and García Osma 2009):

1. Derivatives are assets or liabilities and must be recognised as such in the financial statements.

2. Fair value is the most relevant measurement principle applicable to financial instruments, and the only relevant one for derivatives. Items 
covered with derivatives (hedges) must also reflect the compensatory changes to fair value.

3. Only elements that are assets or liabilities must be recognised as such in the financial statements.

4. Special accounting treatment for hedges must only be allowed for transactions that meet certain requirements and criteria, and one of them should be valuation of compensatory changes at present values or in cash flows.

These basic decisions gave rise to the mixed model -where both historical cost and fair value co-exist as core measurement criteria, and which is the model that is currently in place. Despite several significant initiatives both by the IASB and the FASB to generalize the fair value model to all financial instruments, those intentions have not yet materialized in new standards issued by either of these two main accounting bodies. It is possible that both have deferred this objective sine die, or simply, abandoned it.

In response to these concerns over the measurement of financial instruments, the so called Joint Working Group of Standard Setters (JWG) formed by international specialists, prepared in 2000 a document that suggested the use of fair value for all financial instruments (IASC 2000). However, the proposals contained in that document have not been adopted in practice by any standard setter. According to Morales (2014, p. 73), the key practical problems highlighted by those entities and firms that responded to the JWG proposal were as follows: (i) excessive volatility (particularly for financial instruments for which no active market existed); (ii) excessive costs relative to the benefits it would generate; (iii) subjectivity in obtaining fair values in certain cases; and (iv) problems associated with fair value recognition of financial instruments while retaining other nonfinancial elements at cost.

It is important to note that the current mixed model, applied in many jurisdictions and certainly also present in the IFRS issued by the IASB and the US GAAP issued by the FASB, is not homogenously applied. That is, the application of fair value measurement may be greater in a particular set of standards than in others, without ceasing to be a mixed model. Clearly, this represents a limit to attaining accounting comparability worldwide.

\section{FINANCIAL STATEMENT USERS' PREFERENCES}

The ever-speeding rate of change of current businesses provides the context underlying the previously referred evolution of the objectives of accounting. As noted, the main objective of financial statements at present is to provide information useful for decision making (decision-usefulness paradigm). Among 
financial statement users, it is the providers of capital (both equity and debt) who are currently considered the key users of accounting information.

In a recent review of the literature, Cascino et al. (2013, 2014) identify capital providers as the fundamental users of accounting information. Building on that study, the EFRAG subsequently prepared a document for discussion summarizing the major implications of the study for the issuance of accounting standards (EFRAG 2014). These authors summarize the fundamental uses given to financial statements by capital providers: (1) making economic decisions, including investment decisions (i.e., the valuation role of accounting); and (2) assessing managerial performance (i.e., the stewardship role of accounting).

These documents also indicate plausible preferences of financial statements users to better assess firm future cash flows, as well as identify several other preferences, also documented in prior studies. For example, on the issue of whether the presentation of information matters for investors, Lachmann et al. (2011) find that investors are more likely to use information when it is recognised in the statement of financial position (balance sheet) rather than in the notes to the financial statements. In line with this evidence, Cascino et al. (2013, p. 10) conclude that

"the notes to the accounts are important to professional equity investors, though information recognised in the financial statements receives more attention than disclosures in the notes. There is some evidence that fair value is preferred to historic cost for certain asset classes, but this is not the case where fair value is arrived at using unobservable inputs as part of 'mark to model' valuations."

Importantly, among the preferences of capital providers, the convenience of using fair values remains a controversial and major issue. In particular, Cascino et al., (2013) review of the prior literature concludes, similar to Dutta and Zhang (2002), that while mark-to-market accounting may be desirable from a valuation perspective, it might not be equally desirable from a stewardship perspective. This is because of "its focus on anticipated managerial performance rather than delivered performance." Cascino et al. (2013, p. 10) also note that while measurement at fair value is preferred to historic cost for certain classes of assets, this preference does not extend to cases when "fair value is arrived at using unobservable inputs as part of 'mark to model' valuations."

Both Cascino et al. $(2013,2014)$ and the EFRAG study note the use of the mixed model, and indicate that existing standards often make use of fair value (or other current measures) and cost-based measures, suggesting that fair value is preferred to historic cost for liquid non-operating assets, but only when fair value is arrived at using observable market data. These authors highlight that mark-to-market accounting is problematic (i.e., may lead to inefficacies by creating artificial risk that degrades the information value of prices, and induces 
sub-optimal real decisions) particularly for "assets that are long-lived, illiquid, and senior (i.e. higher in ranking).”

The evidence contained in these studies suggest a number of key points:

1. Among the preferences of users, fair value is the most preferred basis for valuation when it is based on market prices or observable variables, while fair values measured with unobservable values are the least preferred measurement criteria.

2. Financial statement users are sophisticated users that employ different financial statements for different analyses. For example, the statement of financial position is mainly used for valuation, while the profit or loss statement is used both to forecast future cash flows and to assess the performance of managers.

3. Users value the numerical information disclosed in the notes to the financial statements, but place greater value on the information recognized in the primary financial statements.

4. Users consider other comprehensive income (OCI) as valuable to distinguish between different types of performance.

Despite the significant accounting literature supporting these conclusions, it is possible that accounting standard setters do not sufficiently consider these preferences of financial statements users when preparing new accounting standards.

In the next section, and focusing on the use of fair value, we briefly review the content of IFRS 13 ("Fair Value Measurement"), which provides the criteria to calculate fair values under different assumptions. Next, we summarize the content of IFRS 9 ("Financial Instruments") where it is established, among other aspects, the measurement criteria that apply to financial instruments. We also examine whether these standards are aligned with users' preferences as discussed in this section and prior literature.

\section{IFRS 13 (FAIR VALUE MEASUREMENT)}

IFRS 13 defines fair value and determines how to calculate fair value. It applies when another IFRS requires or permits fair value measurement. That is, IFRS 13 does not establish when fair value must be applied; it only regulates how these basic calculations should be made.

To do so, it sets out a 'fair value hierarchy,' by defining three levels of fair value measurement, that in a very simplified manner are as follows:

1. When quoted prices exist in active markets, those prices are the most reliable evidence of fair value and should be used without adjustment to measure fair value. These are level 1 inputs. 
2. When it is not possible to apply level 1 , level 2 fair value can be measured with reference to quoted prices of similar assets or liabilities, and generally, by using accepted formulas and applying it to observable variables.

3. When neither of the previous levels can be used because significant inputs are unobservable, level 3 fair value should be measured using other clearly defined and justified variables.

In addition, IFRS 13 also makes it compulsory to disclose in the notes to the financial statements all data relevant to understand the undertaken valuation processes. ${ }^{6}$

\section{IFRS 9 (FINANCIAL INSTRUMENTS)}

IFRS 9 is effective for annual periods beginning on or after 1 January 2018, and it regulates the accounting treatment of financial instruments. The content of this standard and its differences with its predecessor, IAS 39, have been extensively analysed in recent years. IFRS 9 sets the concepts of 'Business Model' and the SPPI (Solely Payments of Principal and Interest) test to determine the treatment that applies to each financial instrument.

To determine if a financial instrument fails or not the SPPI test, IFRS 9 offers detailed guidance. Basically, a financial instrument should give rise to cash flows that are solely payments of principal and interests (fixed or variable interests) on specified dates. The majority of debt instruments, bank loans, commercial operations, etc., fit this definition, while, obviously, equity instruments do not.

The business model means that firms should take into consideration, for each financial instrument, the way in which the firm will recover its investment, and if it will be via sale of the instrument, through the contractual receipt of cash flows, or both. This classification gives rise to three possible business models that, in turn, have different accounting treatments. Table 1 below summarizes IFRS 9 treatment of financial assets, under the joint application of the SPPI and business model concepts.

Regarding the treatment of financial liabilities, these follow the basic IAS 39 model. That is, except for derivatives and other fair value liabilities through profit or loss, the general measurement criteria that applies to financial liabilities is amortized cost, although it is possible to use the fair value option with changes through profit or loss if that reduces asymmetries or for hybrid financial liabilities. The only relevant change with respect to IAS 39 introduced by IFRS 9 is that, if the firm chooses the fair value option, the changes in value attributable to credit risk must be generally recognised through OCI.

\footnotetext{
${ }^{6}$ Numerous recent studies analyse issues surrounding fair value measurement and provide further details (see, e.g., Argilés-Bosch et al., 2018; Marabel-Romo et al., 2017).
} 
Table 1

Financial Assets Treatment (IFRS 9)

\begin{tabular}{|c|c|c|}
\hline \multicolumn{2}{|c|}{$\begin{array}{c}\text { Financial Assets } \\
\text { (Current model, IFRS 9) }\end{array}$} & \multicolumn{1}{|c|}{ NO SPPI } \\
\hline Business Model & SPPI & \multirow{2}{*}{ FVTPL (2) } \\
\hline Held to collect contractual cash flows only & Amortized cost less impairment (1) & \\
\cline { 1 - 2 } $\begin{array}{c}\text { Held to collect contractual cash flows and for } \\
\text { sale }\end{array}$ & FVOCI (1) & \\
\hline For sale (for default) & FVTPL & \\
\hline
\end{tabular}

SPPI: Solely payments of principal and interest.

FVTPL: Fair value through Profit or Loss Statement.

FVOCI: Fair value through Other Comprehensive Income, other than interest and impairment which are recognized through Profit or Loss Statement.

(1) FVTPL option at inception to reduce accounting mismatches. (Derivatives embedded in a financial asset are not separated)

(2) For shares which are not for sale there is a FV option at inception with changes in OCl, without recycling.

Source: Compiled by the authors.

Going back to financial assets, it can be readily seen that the criteria established by IFRS 9 do not consider fair value levels or the hierarchy of fair value defined in IFRS 13 . This means that the measurement criteria used may not align with the preferences of financial statement users, leading to potential undesirable outcomes. For example, a financial asset measured at amortized cost could be recognized in the statement of financial position at a value higher than its fair value, even when precise and reliable prices can be obtained from an active market, unless the entire difference can be attributed to impairments. Also, taking into account that fair value through profit or loss is the default method; a financial asset could be recognized in the statement of financial position at fair value and give rise to a profit, even when its fair value has been obtained using non-observable variables (level 3).

It is true that the business model may be preferable for the profit or loss statement to better reflect the performance of the firm, but it is not less true that the relevance and faithful representation of information must also be considered. It is at least worth considering that, under this model, it is possible that:

1) A reliable/objective fair value does not appear in primary financial statements.

2) Unreliable fair values give rise to effects that are also unreliable.

The faithful representation and relevance of the statement of financial position may be reduced in cases such as the ones we cite above. We should not forget that, it is not the mission of financial statements to offer a value of the firm, but it is to provide the most appropriate values. Even if all items within the statement of financial position were measured at fair or market values and that process could be conducted using exclusively observable variables, the difference 
between assets and liabilities would still not reflect the value of the firm, given that there could exist assets and liabilities not recognized in the statement of financial position, expectations of future technological changes, etc. This is well accepted both by academics and the accounting profession.

Therefore, the mixed model has advantages and disadvantages, but does not significantly impact the ability of the statement of financial position to measure firm value. However, the mixed model cannot be used as an excuse to include in the statement of financial position unreliable values, or to limit the use of reliable fair values, particularly for the recognition of liquid assets. Given this, we believe it would be preferable to use an alternative approach that, without impairing the objectives that are currently attained, could provide a better alignment with the preferences of financial statements users, and that we detail next.

\section{LONG TERM PROPOSAL}

It is a mammoth (and perhaps unrealistic) task to create a set of accounting standards that meet all the objectives and information needs of all financial statements users, without renouncing to technical soundness, but this should not prevent us from aiming to improve existing regulations. In this paper, we have highlighted several relevant facts. On the one hand, we have described the different uses of financial statements by different capital providers, or the acceptance of OCI in some cases, or the preferences of users with respect to measurement criteria. On the other hand, we acknowledge that it is possible to use OCI for those cases when measurement criteria applied in the profit or loss do not coincide with those used in the statement of financial position (Herranz 1999).

This approach is in line with the draft of the Conceptual Framework issued by the IASB (IASB 2015, p. 71, paragraph 6.77), that expressively mentions:

"In such cases, the total income or total expenses arising from the change in the current value in the statement of financial position is split into two components:

(a) in the statement of profit or loss: the income or expenses measured using the measurement basis selected for that statement; and

(b) in other comprehensive income (see paragraph 7.19): the remaining income or expenses. The cumulative income or expenses included in other comprehensive income equals the difference between the carrying amount determined by the measurement basis selected for the statement of financial position and the carrying amount determined by the measurement basis selected in determining profit or loss.” 
Following on this premise, we could consider that the statement of financial position and the profit or loss statement may have different valuation priorities when offering information to financial statements users. The statement of financial position, geared towards valuation, could use measurement criteria different than those used in the profit or loss statement, which would have a greater orientation towards the assessment of managerial performance as well as the estimation of firm future cash flows.

While the use of different measurement criteria for different financial statements could be extrapolated to other standards, focusing on IFRS 9, an alternative approach could exist, complementing the current one. The measurement criteria currently set in the standard, and that we have reviewed above, could be applied to the profit or loss, and not to the statement of financial position, which could then use different measurement criteria, to avoid running into the type of inappropriate cases that we have detailed (i.e., where unreliable fair values are used and reliable fair values dismissed).

In this way, the changes in value, originated as a consequence of the use of different criteria in the statement of financial position and in the profit or loss statement, would be reflected in OCI, providing better conceptual support for the existence of this statement. Indeed, if one accepts the view that the statement of financial position and the profit or loss statement may have different valuation priorities, this would sustain the existence of OCI as a way to reconcile those differences. OCI would then stop being a 'dump' for those items and valuations that cannot be placed elsewhere and achieve its own conceptual identity. Under OCI firms would recognize the differences between the values reported in the statement of financial position and those used to estimate the profit or loss statement, when they do not coincide as a consequence of the different priorities of those separate financial statements.

The acknowledgement in the conceptual framework of this plausible use of different measurement criteria is a way to recognize that different valuation priorities may exist for different financial statements, even if it is not explicitly indicated.

In practice, the modifications required to IFRS 9 would not be extensive. The measurement criteria that apply to the profit or loss statement could be retained, and only those that apply to the statement of financial position would change.

Conceptually, the differences would be as follows. (1) When the fair value for a financial asset is available, applying solely observable variables, that valuation will appear in the statement of financial position. If that valuation does not coincide with the one used in the profit or loss statement, the difference will be reflected in OCI. (2) When the fair value of a financial asset can only be obtained by using non-observable variables, the statement of financial position will reflect 
that assets for the lower of i) fair value and ii) amortized cost or cost, whichever applies. If that measurement criterion does not coincide with the one used in the profit or loss statement, the difference will be reflected in OCI.

Hence, the measurement criteria of IFRS 9 could be defined in a more detailed manner, maintaining the existing concepts (business model and SPPI), but incorporating an additional concept: the hierarchy in the calculation of fair values, which would be mainly applied in the definition of the measurement criteria to be used in the statement of financial position. Table 2 summarized the model proposed for financial assets.

Table 2

Proposed Model for Financial Assets

\begin{tabular}{|c|c|c|}
\hline \multicolumn{3}{|c|}{$\begin{array}{c}\text { Financial Assets } \\
\text { (Proposed model) }\end{array}$} \\
\hline Financial Position Statement (FP) & $\begin{array}{c}\text { SPPI \& NO SPPI } \\
\text { Any business model (BM) }\end{array}$ \\
\hline Levels 1 or 2 hierarchy (IFRS 13) & \multicolumn{2}{|c|}{ Fair value } \\
\hline Level 3 hierarchy (IFRS 13) & The lower of: (i) Fair value and (ii) Cost or amortized cost as \\
appropriate
\end{tabular}

SPPI: Solely payments of principal and interest.

(1) FVTPL option at inception to reduce accounting mismatches.

Source: Authors's own elaboration.

For financial liabilities, the application of the model would be similar to the current model with respect to profit or loss. In the statement of financial position, and depending on the fair value hierarchy, if the fair value used were level 1 or 2, a financial liability for that fair value would be recognized; otherwise, the higher value between amortized cost and fair value would be used. Any possible differences in measurement between both statements would be recognized in OCI.

Regarding hedge accounting, the proposed model would give rise to some changes with respect to existing criteria. For example, for fair value hedges, when the hedged item is not recognized in the statement of financial position at fair value, differences in measurement from the hedging instrument would be recognized in OCI, being transferred (recycled) to profit or loss at the same rhythm as that the hedged item affected profit or loss, until its final settlement (similar to the cash flow hedge accounting). For cash flow hedges there would 
be no changes with respect to the general criteria. However, when, at their settlement date, they gave rise to the recognition of a non-financial asset or liability, the differences recognized in OCI would not be added to the value of those non-financial items, they would have to follow the general criteria and be transferred (recycled) to profit or loss, as they affected profit or loss.

Of course, arguments exist against this proposed model. For example, it could be argued that it is more complex than the one currently in use, when fair values that do not appear in the firm financial statements are commonly disclosed in the notes. However, it is important to consider that, as previously acknowledged, the measures recognized in the primary financial statements are more relevant to financial statement users than those that are disclosed in the notes. In addition, this apparent greater complexity is compensated amply by the conceptual reinforcement of OCI, which would have an appropriate definition, not only for financial instruments, but also extensible to other cases where measurement in the statement of financial position may not coincide with that presented in the profit or loss statement, given their different priorities.

At present, there is no precise definition of OCI which may help justify its use in the preparation of financial statements. The existing draft of the Conceptual Framework, as we discussed previously, accepts the use of different measurement criteria for the statement of financial position and the profit or loss statement. However, it does not clearly discuss the reasons justifying the existence of those differences, for example, the fact that those financial statements may be used for different decision objectives, justifying the use of different measurement criteria.

In a recent Bulletin (EFRAG 2015, p. 6), the EFRAG indicated that:

"The measurement that is most useful from the perspective of the statement of profit or loss could be expected to be also the most useful from the perspective of the entity's financial position. However, this should not be taken for granted, and questioning whether it is can lead to making the set of financial statements more relevant. Therefore EFRAG supports the ASBJ proposal that the measurement basis selected as the most useful for measuring income and expenses for the statement of profit or loss, is tested to assess whether it is also the most useful for the statement of financial position. If a different measurement basis is chosen for the statement of financial position, the difference should be reported in OCI."

While discussing "long-term investment business models," the same document notes that (EFRAG 2015, p. 10):

"Measurement at cost (less impairment losses) would therefore be relevant from a profit or loss perspective. From the entity's financial position perspective, however, the asset's current value provides relevant information as the ultimate cash inflow is through sale, provided that the asset is in the condition in which it would be sold and there are sufficient 
observable market prices for similar transactions to determine the current value reliably. When these conditions are met, the changes in the value of the investment assets would be reported in OCI. OCI would thus reflect the change in the entity's exposure to market price risk. Accumulated OCI would represent capital appreciation gains accumulated since the acquisition of the investment asset. This amount would be reported separately in profit or loss when the investment asset is sold ('recycling')."

This document suggests a certain degree of acceptance of the existence of different measurement criteria for the statement of financial position and the profit or loss statement, to increase relevance, although the document does not explicitly mention a general criterion at the conceptual level that could justify those potential differences.

In fact, our proposal is consistent with the existing model, and only uses it more precisely, recognizing the possible existence of different information objectives underpinning the use of the different financial statements, and reinforcing the conceptual basis of OCI, as IAS 1 "Presentation of Financial Statements" (IASB 2007) defines total comprehensive income as 'the change in equity during a period resulting from transactions and other events, other than those changes resulting from transactions with owners in their capacity as owners,' including all components of profit or loss and of OCI.

OCI has sometimes been defined as unrealized income or expenses. However, the conceptual differences between realized and unrealized do not feature in the conceptual framework of the IASB, probably because their delimitation is not straightforward. It is true that oftentimes, the items that appear in OCI could be considered as unrealized income or expenses, but it is difficult to generalize this fact to build a definition of OCI. EY (2018, p. 58) mentions that:

"The realisation principle is not discussed in the Conceptual Framework, except to the extent that it is made clear that income and expenses include both realised and unrealised gains and losses. However, the realisation principle appears to have significantly influenced the distinction between items required to be included in profit or loss and those required to be included in other comprehensive income. Many (but not all) items included in other comprehensive income under IFRS would generally be regarded as unrealised."

Using our proposal, financial statements users could evaluate firm performance (income and expenses as defined in the framework) from two points of view: from the view point of the business model through profit or loss, and from the point of view of changes in value in the statement of financial position in Comprehensive Income, being able to examine also through OCI the differences between both calculations. In addition, all items recognized in OCI would be 
eventually recycled to profit or loss, at the time of settlement of the transaction that gave rise to the difference.

This would eliminate existing cases where some items are recognized in the statement of financial position using criteria that do not match the possible information objectives of that statement, by incorporating differences in value that obfuscate the measurement of assets and liabilities and have no clear objective other than to "square up" the differences created by the profit or loss statement objectives.

To sum up, it would attain an 'emancipation' of the statement of financial position, that could then have its own information objective, without interfering with the objectives of the profit or loss statement, and would give OCI the definitive purpose that it currently lacks.

\section{CONCLUSIONS}

(1) Among the different objectives that have been added to accounting, currently, the main one is to provide relevant and faithfully represented information useful for decision making to financial statements users. Accounting may also serve to meet other legal, fiscal and shareholder protection objectives, but these objectives must not limit the fundamental decision-usefulness objective.

(2) Financial statement users are diverse and while all of them should benefit from the information provided by firms in their financial statements, particular attention is given to the information needs of capital providers, both future and present. Capital providers are all providers of capital, both from the debt and equity sides, that provide any manner of finance to the firm.

(3) Capital providers use financial information contained in firm financial statements, jointly with other information available to them, for diverse ends. Among those ends, we can highlight: accounting valuation, estimation of firm future cash flows, etc., that are subsequently used in their valuation and managerial assessment decisions.

(4) Financial statement users utilize the primary financial statements for many decisions, maximizing the decision usefulness of each separate statement. They also use the information contained in the notes, although they assign a lower weight to the information disclosed in the notes, relative to that recognized in the primary financial statements.

(5) Users also positively consider the different performance values available in the profit or loss statement and in OCI. This may give rise to improvements in the conceptual definition and use of OCI, in line with the proposal of the IASB in their Conceptual Framework draft. 
(6) Users prefer fair value measurements, when obtained using observable variables and in relation to active markets. However, this preference disappears when fair value is measured using non-observable variables.

(7) Existing accounting standards are not entirely aligned with the preferences of financial statement users, nor with the possibilities presented by the definition of OCI, which expressively accepts the possibility that different primary financial statements may have different valuation priorities, leading to the presentation of richer information that could benefit from using different approaches to formulate the different primary financial statements.

(8) In the particular case of IFRS 9, it is possible that the existing approach leans towards the objectives of the profit or loss statement, without paying sufficient attention to other objectives, equal in rank, which could be met by the statement of financial position, by adequately using the concept of OCI.

(9) The existing formulation of IFRS 9 may give rise to non-desirable outcomes, at least from the point of view of the statement of financial position. For example, an amortized cost higher than a level 1 fair value may be recognized, or a level 3 fair value greater than the amortized cost or cost. That is, it does not consider the fair value hierarchy established in IFRS 13, which is particularly worrisome when financial statement users appear to reject fair values that are measured using exclusively non-observable variables.

(10) Given this, it is possible to suggest a new model that, without differing from the essence of the measurement criteria proposed by IFRS 9 to determine impacts on the profit or loss statement, can introduce different parameters for accounting measurement in the statement of financial position. Those parameters would be oriented towards: (a) Considering the level used to obtain the fair value; (b) Considering the different potential priorities for the profit or loss statement and the statement of financial position; and (c) Suggesting a definition of OCI in the new IASB Conceptual Framework.

(11) Given this, IFRS 9 could maintain the existing criteria of SPPI and business model, to determine the impacts on the profit or loss statement, but introduce in the statement of financial position different valuation priorities to address the needs of users. The valuation differences between both primary financial statements would be recognized in OCI.

(12) It is true that, currently and given the recent application of IFRS 9 in January 2018, it is not the best time to suggest modifications, but we understand that certain conceptual aspects that are contained in this proposal may be considered in the mid- and long-term, not only with respect to the measurement of financial instruments, but also, to other elements of the financial statements. 


\section{BIBLIOGRAPHY REFERENCES}

ARGILÉS-BOSCH, J.M., MIARONS, M., GARCÍA-BLANDON, J., BENAVENTE, C., and RAVENDA, D. (2018). "Usefulness of Fair Valuation of Biological Assets for Cash Flow Predictions". Spanish Journal of Finance and Accounting, Vol. 47, No. 2, pp. 1-29.

BARRÓN, I. (2013). "El Supervisor Aflora 21.000 millones de Morosidad Oculta en Refinanciaciones". El Pais, November 6. Available online at: https://elpais.com/ economia/2013/11/06/actualidad/1383731942_612374.html

CAÑIBANO, L., GARCÍA, M. and SÁNCHEZ, M. P. (1999). "La Relevancia de los Intangibles para la Valoración y la Gestión de Empresas: Revisión de la Literatura". Revista Española de Financiación y Contabilidad, Vol. 28, No. 100, pp. 17 - 88.

CAÑIBANO, L. and HERRANZ, F. (2013). "Principios versus Reglas en las Normas Contables." Revista Consejeros, No. 80 (February), pp. 56-72. Available on line at: http://www.aeca.es/faif/articulos/consejeros_feb13.pdf

CASCINO, S., CLATWORTHY, M., GARCÍA OSMA, B., GASSEN, J., IMAM, S., and JEANJEAN, T. (2013). "The use of information by capital providers. Academic literature review". ICAS \& EFRAG. London. Available online at: http://www.icas.com/ technical-resources/the-use-of-information-by-capital-providers.

CASCINO, S., CLATWORTHY, M., GARCÍA OSMA, B., GASSEN, J., IMAM, S., and JEANJEAN, T. (2014). "Who Uses Financial Reports and for What Purpose? Evidence from Capital Providers." Accounting in Europe, Vol. 11, No. 2, pp. 185-209.

DELGADO, C. (2012). "El Banco de España Pone Coto a la Morosidad Oculta con Refinanciaciones". El País, October 3. Available online at: https://elpais.com/ economia/2012/10/02/actualidad/1349210075_204888.html

DUTTA, S. and ZHANG, X.-J. (2002). "Revenue Recognition in a Multiperiod Agency Setting". Journal of Accounting Research, Vol. 40, No. 1, pp. 67-83.

EFRAG. (2014). The Use of Information by Capital Providers. Implications for Standard Setting. Short Discussion Series. EFRAG. Brussels. Available online at: http://old.efrag.org/Front/n1-1254/EFRAG-paper-on-the-implications-for-standardsetting-following-from-the-use-of-information-by-capital-providers.aspx

EFRAG. (2015). Getting a Better Framework. Profit or Loss versus OCl. Bulletin. EFRAG. Brussels. Available online at: http://www.efrag.org/News/Project-129/EFRAGpublishes-a-Bulletin-on-profit-or-loss-versus-OCl-

EY International Financial Reporting Group (EY) (2018). International GAAP 2018. Generally Accepted Accounting Practice under International Financial Reporting Standards. John Wiley \& Sons. Chichester.

HERRANZ MARTÍN, F. (1999). "Tendiendo Puentes entre el Balance y la Cuenta de Resultados" Revista AECA, No. 49, pp. 46-48. Available online at: http://www.aeca1.org/revistaeca/revista49/49.pdf

HERRANZ, F. (2001). Los Derivados y el Riesgo de Mercado. AECA: Madrid. Available on line at: http://www.aeca.es/faif/articulos/losderivadosyelriesgodemercado_fherranz.pdf

HERRANZ, F and GARCÍA OSMA, B. (2009). "Background and Recent Developments in Fair Value Measurement: From FASB's 1996 Four Decisions to the Recent Financial Crisis." Spanish Journal of Finance and Accounting, Vol. 38, No. 144, pp. 647-662. Available online at: http://www.aeca.es/old/faif/articulos/the4Decisions1996.pdf 
INTERNATIONAL ACCOUNTING STANDARDS BOARD. IASB (2015). Conceptual Framework for Financial Reporting. Exposure Draft ED/2015/3. IASB: London. Available online at: http://archive.ifrs.org/Current-Projects/IASB-Projects/ConceptualFramework/Documents/May\%202015/ED_CF_MAY\%202015.pdf

INTERNATIONAL ACCOUNTING STANDARDS BOARD. IASB (2014). International Financial Reporting Standard. IFRS 9. "Financial Instruments"

INTERNATIONAL ACCOUNTING STANDARDS BOARD. IASB (2011). International Financial Reporting Standard. IFRS 13. "Fair value measurement"

INTERNATIONAL ACCOUNTING STANDARDS BOARD. IASB (2007). International Accounting Standard 1. IAS 1. "Presentation of Financial Statements"

INTERNATIONAL ACCOUNTING STANDARDS COMMITTEE. IASC (2000). Draft Standard and Basis for Conclusions Financial Instruments and Similar Items. Joint Working Group of Standard Setters. IASC. London. Available online at: https://www.iasplus.com/en/binary/resource/fijwg-0.pdf

LACHMANN, M., WÖHRMANN, A. and WÖMPENER, A. (2011). "Acquisition and Integration of Fair Value Information on Liabilities into Investors' Judgments." Review of Accounting and Finance, Vol. 10, No. 4, pp. 385- 410

MARABEL-ROMO, J., GUIRAL, A., CRESPO-ESPERT, J.L., GONZALO, J.A., and MOON, D. (2017). "Fair Value Accounting in the Absence of Prudence in Accounting Standards: An Illustration with Exotic Derivatives." Spanish Journal of Finance and Accounting, Vol. 46, No. 2, pp. 145-167.

MORALES, J. (2014) Análisis del Modelo Full Fair Value bajo el Paradigma de la Utilidad: un Estudio Empírico". PhD thesis, Universidad Complutense de Madrid. Available online at: http://aeca.es/wp-content/uploads/2014/05/tesis_jmd.pdf

MORALES, J. (2017). "Fair Value in Financial Instruments Accounting. Analysis from a Historical Perspective." De Computis. Spanish Journal of Accounting History, Vol. 26, pp. 90-154. Available online at: http://aeca.es/wp-content/uploads/2014/05/299-10941-PB.pdf

MUÑOZ, M. and HERRANZ, F. (2010). "La Contabilidad: Una Crónica Fugaz Española," in CAÑIBANO, L. (ed.) "RAFAEL MUÑOZ RAMÍREZ. EMPRESARIO Y DOCENTE. LIBRO-HOMENAJE," pp. 137-168. AECA: Madrid. Available online at: http://www.aeca.es/temporales2012/empresario_y_docente.pdf

NOBES, C.W. (1983). "A Judgmental International Classification of Financial Reporting Practices." Journal of Business Finance and Accounting, Vol. 10, No. 1, pp. 1-19.

NOBES, C.W. (2004). "On Accounting Classification and the International Harmonization Debate." Accounting, Organizations and Society, Vol. 29, No. 2, pp. 189-200. 
